\title{
Special Education in Saudi Arabia: History and Areas for Reform
}

\author{
Rashed A. Aldabas \\ Department of Special Education, University of Northern lowa, Cedar Falls, USA \\ Email: aldabasr@uni.edu
}

Received 31 March 2015; accepted 23 June 2015; published 26 June 2015

Copyright (C) 2015 by author and Scientific Research Publishing Inc.

This work is licensed under the Creative Commons Attribution International License (CC BY). http://creativecommons.org/licenses/by/4.0/

(c) (i) Open Access

\begin{abstract}
The purpose of this paper is to examine and conduct a historical overview of special education in Saudi Arabia. Special education has existed in Saudi Arabia since 1958 and has made considerable progress in providing services to students with disabilities. However, there is still a need for improvement in educating students with disabilities and in the movement toward inclusive education. Providing free and appropriate public education for such students should be the purpose guiding special education in the country. This paper discusses the areas that need to be improved in order to ensure that students receive the best possible education within inclusive learning environments.
\end{abstract}

\section{Keywords}

Special Education, Students with Disabilities, Special Day School, Special Education Law, Transition Services, Teacher Education, Inclusive Education

\section{Introduction}

The field of special education was developed because many students with disabilities could not benefit from the existing general public education system. Each country across the world has developed its own system of providing special education services and has made improvements in its education system year by year. Saudi Arabia is one of the countries where special education is developed and has changed over time in order to support learning for students with disabilities. Throughout this paper, the special education system will be explored historically and developmentally.

This paper attempts to determine how special education has been developed in Saudi Arabia and how it can be improved, based on the calls for the establishment of inclusive classrooms for students with disabilities. It will examine at what level special education develops and how it can be upgraded. At present, there are calls 
across many nations, including Saudi Arabia, to embrace inclusion in the learning environment for students with disabilities. However, it is imperative to note that much restructuring is required if such inclusion is to be attained in Saudi Arabia.

The paper begins by presenting the historical overview of special education in Saudi Arabia, especially the progress in educating students with disabilities. It then explores the forces driving the need for changes in special education. The first of the paper's three main parts presents an analytical review of the critical area in special education that requires policy change. The second section discusses aspects of teacher competencies and how they are enshrined in the dynamics of special education. The last part of the paper explores the modalities of embracing inclusion for students with disabilities in Saudi Arabia.

\section{Historical Timeline of Special Education in Saudi Arabia}

Before 1958, the Saudi Arabian government did not provide special education services for children and individuals with disabilities. According to Al-Ajmi (2006), children with special needs depended entirely upon their parents for any educational support. Salloom (1995) stated that special education started 1958 as a training program on how to read Braille. The services were provided only for blind adults, and there were no young people involved nor were there any services for categories other than blindness and visual impairments (Al-Wabli, 1996). Table 1 outlines the dates and special education services that were provided.

Table 1. Summary of historical time line of Saudi Arabia in special education.

\begin{tabular}{|c|c|c|c|}
\hline Year & Type of Disability & Placement & Note \\
\hline 1958 & Blindness (men) & $\begin{array}{l}\text { Private Place/ } \\
\text { nonprofit group. }\end{array}$ & $\begin{array}{l}\text { A blind man started to learn to use the Braille System. } \\
\text { Small group training in Braille }\end{array}$ \\
\hline 1960 & Blindness (boys) & Special Day School. & $\begin{array}{l}\text { Sponsored by Ministry of Education. } \\
\text { Special school for blind males (Al-Noor Institute) } \\
\text { various ages. }\end{array}$ \\
\hline 1962 & - & - & $\begin{array}{l}\text { Administration of Special Education established by } \\
\text { Ministry of Education }\end{array}$ \\
\hline 1964 & Blindness (girls) & Special Day School. & $\begin{array}{l}\text { Sponsored by Ministry of Education- Administration of } \\
\text { Special Education } \\
\text { Special School for blind girls (Al-Noor Institute) various } \\
\text { ages. }\end{array}$ \\
\hline 1964 & Deafness (boys) & Special Day School. & $\begin{array}{l}\text { Sponsored by Ministry of Education- Administration of } \\
\text { Special Education. } \\
\text { Special Schools (Al-Amal Institute) various ages }\end{array}$ \\
\hline 1964 & Deafness (girls) & Special Day School. & $\begin{array}{l}\text { Sponsored by Ministry of Education- Administration of } \\
\text { Special Education. } \\
\text { Special Schools (Al-Amal Institute) various ages }\end{array}$ \\
\hline 1971 & Intellectual disabilities & $\begin{array}{l}\text { Special Day School. } \\
\text { Residential School. }\end{array}$ & $\begin{array}{l}\text { Sponsored by Ministry of Education- Administration of } \\
\text { Special Education }\end{array}$ \\
\hline 1974 & - & - & Ministry of Education \\
\hline $\begin{array}{c}\text { Between } \\
1960-1987\end{array}$ & $\begin{array}{l}\text { Blindness, Deafness, Intellectual } \\
\text { Disabilities }\end{array}$ & $\begin{array}{l}27 \text { Institutes special day } \\
\text { schools and some residential } \\
\text { schools. }\end{array}$ & $\begin{array}{l}10 \text { for deaf; } 6 \text { males } / 4 \text { females. } \\
10 \text { for blind; } 7 \text { males } / 3 \text { females. } \\
7 \text { for mental retardation; } 4 \text { males } 3 \text { females }\end{array}$ \\
\hline $\begin{array}{c}\text { Between } \\
1987-1990\end{array}$ & $\begin{array}{l}\text { Blindness, Deafness, Intellectual } \\
\text { Disabilities }\end{array}$ & $\begin{array}{l}54 \text { special day schools and } \\
\text { some residential schools. }\end{array}$ & $\begin{array}{l}\text { Sponsored by Ministry of Education- Department of } \\
\text { Special Education }\end{array}$ \\
\hline $\begin{array}{c}\text { Between } \\
1990-2000\end{array}$ & $\begin{array}{l}\text { Mild and moderate Intellectual } \\
\text { Disabilities, Autism, hard of } \\
\text { hearing, Hearing Impairments }\end{array}$ & $\begin{array}{l}\text { Full-time special education } \\
\text { classrooms in public schools }\end{array}$ & $\begin{array}{l}\text { Sponsored by Ministry of Education- Department of } \\
\text { Special Education }\end{array}$ \\
\hline Currently & $\begin{array}{l}\text { Mild to Moderate Learning } \\
\text { Disabilities }\end{array}$ & $\begin{array}{l}\text { General education } \\
\text { classrooms with resources } \\
\text { rooms' assistance. }\end{array}$ & $\begin{array}{l}\text { Sponsored by Ministry of Education- Department of } \\
\text { Special Education }\end{array}$ \\
\hline Currently & $\begin{array}{l}\text { Moderate, Profound and Severe } \\
\text { Disabilities including Intellectual } \\
\text { Disabilities, Autism, } \\
\text { Deafness-Blindness, multiple } \\
\text { Disabilities. Physical Disabilities }\end{array}$ & Special day schools. & $\begin{array}{l}\text { Sponsored by Ministry of Education- Department of } \\
\text { Special Education. } \\
\text { Ministry of Social Affairs }\end{array}$ \\
\hline
\end{tabular}


According to Al-Kheraigi (1989), the first special education programs formally provided in Saudi Arabia in 1958 and included services for blindness in which a blind man introduced a system to support blind adults in learning to use Braille. This service was offered and funded by a private organization and offered during the evening, only in Riyadh and only for blind people (Al-Kheraigi, 1989). As can be seen in Table 1, there was no special education system or government agency supporting and supervising these special education programs.

Two years after the non-profit organization in Riyadh opened the Saudi Arabian government opened the first special school, the Al-Noor Institute, for the blind. The Al-Noor Institute of Riyadh was the first educational facility for the vision-impaired and formed the basis of public special education (see Table 1). Supported by the Ministry of Education in 1960, the Al-Noor Institute of Riyadh was a special school for educating male individuals with poor vision, blindness or visual impairments. It trained various ages and placements from the elementary level through middle school and ending in high school. The curriculum was the same as the general education curriculum except where instruction was adapted to meet the needs of students with visual impairments. Al-Noor Institute focuses on teaching visually impaired students using Braille and similar systems to teach such humanities courses as Islam, social sciences, and Arabic sciences. The curriculum also included training on orientation and mobility. Some of Al-Noor Institute teachers are blind.

In 1962, the Ministry of Education established the Saudi Arabian Special Education Unit to offer rehabilitation and educational services to individuals with visual impairments or blindness, and others who were not otherwise served, such as those who were deaf, had impaired hearing or had intellectual disabilities (Afeafe, 2000). Al-Mousa (1999) declared that the government of Saudi Arabia established three institutions, in Alhofouf, Aneaza, and Mecca, in 1964 in order to meet the special needs of individuals with visual impairment or blindness. All these institutes were under the name of the Al-Noor Institute and were supported and operated by the Saudi Arabian government through the Ministry of Education, the Special Education Unit.

These three Al-Noor institutes were only the first educational institutes to be sponsored and supervised by the Ministry of Education. In 1964, the first Al-Noor Institute for blind girls was opened and provided educational and training services for girls with visual impairments or blindness (see Table 1). These services included training in using Braille for educational purposes or for work. Girls at the Al-Noor Institute were of various ages and educational placements and received instruction in humanities courses such as Islam, social sciences, and Arabic sciences. In short, between 1962 and 1964 the special education programs and services were provided only for individuals with visual impairments.

Al-Amal Institute was the first school to educate students with hearing impairments and deafness. In 1964, the Ministry of Education established in Riyadh two Al-Amal Institutes, one for boys and another for girls (see Table 1). This institute focused on teaching sign language to students of various ages and placements, with a curriculum duplicating the general education curriculum, including Islam, Arabic sciences and math with adaptations, using sign language to teach and meet the needs of deaf students. The teachers' skills varied, some specialized in teaching students with hearing impairments and others used and translated sign language.

From 1960 to 1971, special education programs in Saudi Arabia expended from limited services for a specific disability to opening the Special Education Agency in the Ministry of Education. This included opening special education schools for male and female students both with hearing and with visual impairments and increased the number of special day schools for those students. In 1971, the Ministry of Education opened the first special school, the Intellectual Education Institute, to educate students with intellectual disabilities (see Table 1). This institute provided special education and training as well as housing for boys and for girls with severe and profound intellectual disabilities. The curriculum was focused on developing social, behavioral and daily life skills (Al-Wabli, 1996). These special institutes provided residential services for students with intellectual disabilities similar to those the Ministry of Social and Labor Affairs provided for them. However, the Intellectual Education Institute services focused on improving the social behavior and communication skills of the students.

According to Al-Kheraigi (1989), by 1987 a total of 27 special education schools and institutes had opened to serve blind and deaf students and those with intellectual disabilities across Saudi Arabia. These schools included ten Al-Noor Institutes, ten Al-Amal Institutes and seven Intellectual Education Institutes. The increase was gradual from the 1960 fiscal year when there was just one school for the blind to 27 special education schools for different types of disabilities in the year 1987 (see Table 1).

Special education in Saudi Arabia saw further development between 1987 and 2000, and the total number of special education schools increased to 54. A significant part of the improvement was providing services for students with learning disabilities in public schools through resource rooms. Such services were not offered until 
1990 because there was limited knowledge about learning disabilities. Changing the educational placement of students with disabilities from separate schools to special education classrooms within public schools also occurred between 1990 and 2000 (Al-Mousa, 2010). The Department of Special Education has opened special education schools within public schools for students with mild to moderate intellectual disabilities, mild to moderate autism disorders and hearing impairments (Al-Mousa, 2010). The students have received special education services though these special classrooms as educational placement.

Special education classrooms for students with mild to moderate disabilities including intellectual disabilities, and autism and hearing impairments have continued to be opened in selected public schools. In fact, today across the country approximately 746 public schools have special education classrooms for students with mild to moderate disabilities including intellectual disabilities and multiple disabilities as well as 47 programs for students with mild to moderate autism disorders. In public schools throughout Saudi Arabia there are about 316 programs for deaf students and those with hearing impairments and 171 programs for blind students and students with visual impairments (Ministry of Education of Saudi Arabia, 2012). Furthermore, within 1417 programs, students with learning disabilities have been provided part-time special education services during their school day within the resource rooms, as they have been fully included in the general classrooms in public schools (Ministry of Education of Saudi Arabia, 2012; Al-Otaibi \& Al-Sartawi, 2009). However, students with severe and multiple disabilities are still served in special schools (Alquraini, 2011). Still, no unique services are provided for other categories of disabilities, such as Behavioral and Emotional Disorders (BED) as well as Attention Deficit and Hyperactivity Disorder (ADHD) as these seem to be disorders rather than a type of disability.

\section{Driving Force for Changes in Special Education}

This section explores the forces that drive the need for change in special education in Saudi Arabia and is divided into three main parts. The first presents an analytical review of critical areas requiring policy change that will result in better services for children and adults with disabilities. Educating children with disabilities in general classrooms is one of the most desirable ways through which the needs of these students can be understood clearly by the educational specialists, thereby giving them a chance to tailor policies that meet the learning needs of students with disabilities (Loiacono \& Valenti, 2010). The second section explores the aspects of teacher competencies and how they are enshrined in the dynamics of special education. The last part explores the modalities of embracing inclusion for students with disabilities.

\subsection{Laws for Considering Eligibility for Special Education Services}

Cushing, Clark, Carter, \& Kennedy (2005) noted that the enhancement of legislation on inclusion is the most important issue in special education policy. It is easy to derive policy goals and objectives in special education development from the general legislation on discrimination. Merging legislation on the social aspect of life at the state and country levels is a first step in the development of policies and educational legislation that support the inclusion of students with disabilities. This is not merely a process of eliminating discrimination in education, but is also one of enhancing learning competencies for children with disabilities. Inclusive education will support students with disabilities being a part of their community and thus will improve their social, behavioral and learning abilities.

The need to provide high-quality special education services to individuals with disabilities in Saudi Arabia necessitates the establishment of laws to ensure the hiring of education experts, improve the value of services for special education, and guarantee the privileges of individuals with disabilities in the country. In addition, the regulations have assisted in providing and advancing special education programs in the country. The rules and policies that have been established in Saudi Arabia are described next.

Saudi Arabia instituted Rules and Regulations of Special Education Programs (RRSEP) in 2001 to establish the privileges and policies that rule the right of students with disabilities to have access to special education programs. Moreover, the regulations highlight key groups of students with various disabilities such as blindness, deafness, hearing impairments, learning disabilities, intellectual disabilities and autism. Based on the nature of the disability, the government evaluates whether a student is entitled to an individual or a joint special education program. Through this law, every student with special needs is entitled to the transition education and associated services, early intervention programs, and individual educational programs, as well as to appropriate and free special education (Ministry of Education of Saudi Arabia, 2002; Alquraini, 2010). 
RRSEP was created to ensure that each student with any category of disability receives special education services depending on his or her needs. RRSEP was recognized by the Department of Special Education under the Ministry of Education of Saudi Arabia and was meant just for educational and schooling purposes. However, implementation of RRSEP policies has had limited effectiveness for different reasons; for example, lack of experts in conducting diagnostic assessments and no effective assessment tools by which to determine the best educational settings that meet different needs of the students and where they are located. In spite of the limitations, RRSEP has provided clarification on administration and leading special education services, for instance, where and which educational placements are available to each category of disability, activities and transportation or special education students.

RRSEP also specifies the requirements and conditions which qualify a student to be served with special education services. RRSEP, moreover, focuses on providing special education services to students with disabilities in special educational institutes and schools or through special education classrooms or resources rooms in public schools. Special education services are offered to primary, elementary, middle school and high school students either in special education schools or in special education classrooms in public schools. However, RRSEP does not include information about full inclusion of students with disabilities, Least Restrictive Environment (LRE) or early intervention services as the Individuals with Disabilities Education Act (IDEA) of the United States do.

Another law established by the government of Saudi Arabia in 2000 was the Disability Law. This regulation ensures that each person with a disability can access appropriate and free rehabilitation, educational and mental health services offered via public organizations. Through these agencies individuals with disabilities have the right to access and reserve special education and rehabilitation services (Alquraini, 2010). Under this law, individuals with special needs have the right to access public services provided by all public agencies including making modifications of public attractions and services in order to make them available for the individuals.

The law indicates that individuals with disabilities are guaranteed a free and appropriate life in a way that meets their needs. The concept of Least Restrictive Environment (LRE) is mentioned throughout this law as individuals with disabilities should be able to benefit from all the services provided in public agencies or by the government. The law also states that public agencies should provide special services to individuals with disabilities and make their services accessible to the individuals who need them. Individuals with disabilities are welcome and able to attend public festivals or be in public as this law requires all public facilities to be modified to be appropriate for individuals with disabilities. It specifies that health, education, social and financial services should be provided to all individuals with disabilities without discrimination or isolation. Thus, this law maintains the rights of individuals with disabilities and guarantees them a free and appropriate life, depending on their needs. Finally, in Saudi Arabia it is important to clarify for the educational community such as teachers and students, as well as Saudi society as a whole the policies of education concerning students with disabilities.

\subsection{Early Identification and Intervention}

The most resounding thing is the development of a policy framework in the social environment that requires parents to bring to the attention of schools children who either directly or indirectly exhibit signs of disability (Proctor \& Niemeyer, 2001: pp. 55-60). However, laws and policies of early identification and intervention services are not mandated in Saudi Arabia. This is regarded as a desirable step when it comes to grouping these children and identifying the best modalities of learning and delivery for all children with special needs (IDEA Partnership, 2007: pp. 5-10). Indeed, the government of Saudi Arabia should establish policies that require provision of early identification and intervention in special education. Special education services, including early identification and intervention, should be provided for all individuals beginning at birth in order to develop an effective plan for each child who may have a disability. Moreover, to enhance providing quality early identification and intervention services, Saudi Arabian educational and government health agencies, including community agencies, should work together.

\subsection{Parent Involvement}

Resch et al. (2010) noted the value of engaging parents in the enhancement of learning for students with disabilities. Parents occupy center stage in the development of their children, thus one of the elements of inclusion for students with disabilities is the involvement of parents in modeling learning for them. According to Worcester et 
al. (2008), parents have a significant role of enhancing the acceptance of children with disabilities in society through the development of a landscape that supports interaction between children with and children without disabilities. At this level, it is worthwhile to cite a quote from Will (1986), who asserted that, "An appropriate mechanism for assuring the parental involvement would be parent advisory boards to assist schools in determining ways to more effectively involve parents in their children's education" (p. 414). The level of acceptance attained in the realm of disability acceptance in society plays a vital role in the attainment of the goals of inclusion as most of these goals are modeled on the social aspects of development and coexistence in society. According to Smith (2006), peer interactions combine with parental advocacies to increase the level at which inclusive learning is done in schools that embrace inclusion for children with special needs.

Parental involvement should be invited and nurtured in schools, not just for students with disabilities, but for other students as well. Since there is parent involvement in the teaching process, unique needs of students would be met and then the students would be successful in their learning and life. Schools should make efforts to encourage parents to participate in planning for their children's learning, inviting parents to become involved in teaching their children. When schools and homes work together, students will improve, their goals will be met and inclusive education will be made easily available as well.

Parent involvement is an essential support for inclusion of students with disabilities in general classrooms. Schools should require parents to be involved and take an active role in the education of their children. In the same way, the Saudi education system should require schools to invite parents to share in educating their children. It is important to inform parents about their importance and their right to be involved in educating their children. Teachers, too, should be aware of the significance of parent involvement.

\subsection{Assistive Technology}

Russell, Bebell, O'Dwyer, \& O'Connor (2003: p. 297) recommended the use of technology as a tool for improving learning. To what level can high, medium or low technologies be deployed in the Saudi Arabian education system that embraces inclusive learning? An assessment of the models of technology deployment in education indicates the prevalence of challenges in technology adoption. This applies as well to learning environments that are not inclusive. Thus, the development of learning competencies might be difficult to attain when deployed in a collective learning environment. Assistive technology should be introduced and be accessible for all teachers. There is also a need to tailor assistive technology to make it applicable in an inclusive learning environment, owing to the fact that learning in such an environment cannot be easily attained when the aspects of technology are not deployed appropriately. Wong, Li, Choi, \& Lee (2008) noted that technology, when applied in education, can only be meaningful when it enhances the competency levels of the students and the teachers. Another observation is that technology results in the attainment of educational goals when it is deployed based on the social models that support learning and learning competencies (Alquraini \& Gut, 2012: pp. 42-49). Indeed, skills and knowledge of the use of assistive technology in classrooms should be provided for in-service teachers through professional development programs and as courses for student teachers and pre-service teachers in Saudi Arabia.

\subsection{Accommodation and Modification of General Education Curriculum and Setting}

One thing common among students with disabilities is that their conditions make it quite daunting to acquire and develop learning competencies, thus the need for special support. This support is the virtue of using physical tools to enhance learning or the modeling of behavior through deployment of social and learning models in educating students in Saudi Arabia. Classroom, instructional, assignment, grading and accessibility modifications should be considered before inclusion of students with disabilities takes place in general classrooms. In fact, it is difficult to place students with disabilities in general classrooms without making required modifications in classrooms, textbooks and instructions.

Instructional and curricular modifications are important for inclusion of students with disabilities in general classrooms (Alquraini \& Gut, 2012). This involves what takes place inside the classroom, including curricular adjustment to fit the needs of the students, as well as advanced notice of assignments, a syllabus and different forms of teaching or presenting assignments. An example would be a case where homework is presented orally instead of as written assignments. Time and reporting time is another area that can be adjusted to ensure that the student fits in and benefits from the inclusion. The school system should take care of the needs of students with 
disabilities and support them so they benefit from their placement in general classrooms. All the above suggestions will enhance inclusive education in Saudi Arabia.

\subsection{Transition Services and Related Supports}

According to IDEA Partnership (2007: pp. 4-6), the transition in special education is an issue that requires policy considerations to enhance incremental progress for the regular students and the students with special needs. One of the main considerations receiving a lot of attention from researchers is the need to prepare students with disabilities for adult life after school. The Saudi Arabian special education system should aim to support students with disabilities living as independently as possible. This cannot be achieved without providing transition services for the students. Thus, the development of transition programs for students will address the essential goals of special education services, which include independent living. Moreover, special education teachers should involve other individuals who may support students with disabilities in their transition from special education classrooms to general classrooms, from one grade to another and from school to work. Importantly, transition goals should be planned with collaboration with others in order to help the students succeed in their next life.

\subsection{Preparation Programs for Future Special and General Education Teachers}

Currently, no general teacher preparation programs in Saudi Arabia offer any courses that address special education. As a result, Saudi teachers in public schools are often unprepared for inclusive education and how to address the needs of students with diverse characteristics. Most of the education programs in Saudi Arabia depict the invention of programs that focus on preparing teachers for meeting the needs of all students. This points to the development of schooling environments that support students with and students without special needs (Johnson \& Merrill, 2000: pp. 3-5). Hence, special education courses such as diversity needs among leaners, foundation of special education and inclusive education should be included in teacher preparation programs. When general education teachers have enough clear knowledge about the meaning of special education, inclusion of students with disabilities in general classrooms will be enhanced and effective. Special education preparation programs also should include courses that address evidence-based practices and research in special education. Preservice special education teachers should be knowledgeable regarding the effective and functional interventions in order for there to be qualified special education teachers in schools. Moreover, student teaching and field experiences in both general and special education programs should be to prepare teachers to teach in inclusive classrooms. The Ministry of Education in Saudi Arabia should develop hiring qualifications for teachers and these should be included in teacher preparation programs in colleges of education in Saudi Arabian universities.

\subsection{Professional Development Programs for Current Special and General Education Teachers}

Forlina \& Chambers (2011: p. 17) observed that one of the challenges in professional development is to prepare teachers to meet the needs of students with disabilities. The question here is whether teachers in general education settings can be deployed in inclusive educational settings. Preparing teachers for inclusion is a comprehensive activity that requires understanding the nature of disabilities inherent in a given learning environment. There is a need in Saudi Arabia to offer professional development programs for all in-service teachers focusing on inclusive education and how to deal with students with disabilities in their classrooms. It is crucial that professional development programs concentrating on inclusive education be established in order to move toward full inclusion for students with disabilities.

Professional development programs should be offered throughout the school year for all special and general education teachers. These programs should include information about what the effective instructions and educational interventions are and should focus on evidence-based practices in teaching and special education. For example, to improve staff teaching skills schools should provide during the school day programs geared to improve teaching skills, including how to deal with behavior problems and how to teach students with disabilities in general classrooms. These programs can emphasize working together in teams. Special and general education teachers should be aware of the methods of collaboration. 
Collaboration methods, such as professional learning communities and co-teaching, will be effective for supporting students with disabilities in general classrooms as they provide opportunities for all teachers to work together in meeting diversity needs among learners in one classroom. According to Burnette (2002), through the professional learning community, all educational staff in one school work as a team with the same aims to archive and involve all in the learning and development circles in order to resolve daily schooling problems. Action would then be taken to improve the learning of students as the essential goal. Therefore, the involving the professional learning community will be the best practice to improve skills of teachers in schools as they have their own professional team. A professional learning community should be built in each school across Saudi Arabia.

Professional development programs should prepare teachers to develop and use assistive technology for teaching. Assistive technology is seen as a strategy to enhance educating students with disabilities both in special education and in general education classrooms. Assistive technology supports teachers in meeting the unique needs of their students and improving teachers' skills, as well. Workshops and conferences should address new instructional methods, issues and applications in teaching general as well as special education. All teachers should be invited to attend and participate in order to open inclusive education schools in Saudi Arabia.

Inclusive education can be achieved through establishing a continuous process of curriculum development, whereby the best attributes of learning are extracted from regular classrooms and special classrooms so complete and efficient curricula are created and inclusive learning is achieved. Within such a school, all teachers would work together in team teaching. Not only does such team-teaching help students succeed in their learning, it also improves teaching skills as teachers learn from each other. Indeed, all the above professional development needs can be resolved by applying the professional learning community method. It should be considered in the education system of Saudi Arabia in order to achieve the goal of inclusion of students with disabilities in general classrooms.

\subsection{Preparation Programs for Other Educational and Schooling Professionals}

Rethinking the development of professionalism among teachers requires consideration of other individuals who may be involved in educating students with disabilities. At present it is hard to see collaboration between general and special education systems in Saudi Arabia. As a result, inclusion of students with disabilities would not be effective. The special education system in Saudi Arabia should take the initial action to collaborate with the general education system so both systems work together for successful inclusive education. For example, principals, social workers, school psychologists, school consultants, and speech-language pathologists are all involved in inclusion of students, so they should work as a team for improving students` skills. For that reason, all these individuals should be provided professional development programs focusing on special education, how to deal with the education and behavior of students with disabilities, inclusive education and collaboration.

Moreover, all those individuals, including general education and special education teachers, should be effective members in the Individualized Education Program (IEP), for supporting the students to benefit from education and as well as inclusion. In addition to the professional development programs offered to those individuals, all other individuals in school communities, such as students without disabilities, parents and neighbors, should be considered for inclusion in awareness programs. In other words, all individuals involved in general and special education fields should be prepared for inclusive education.

\section{Conclusion and Recommendations}

In Saudi Arabia, special education has come a long way in assisting students with disabilities to obtain free, valued and appropriate education. The history of education in Saudi Arabia indicates that the provision of special education services has progressed significantly over the past 50 years. The Ministry of Education, Special Education Department, has worked with other organizations to ensure that appropriate education is provided and that professionally competent teachers are prepared to handle and educate students with special needs. For example, educational services that were initially provided through small groups and only for visually impaired male individuals were later expanded to both female and male students who were deaf or hearing-impaired, and had intellectual disabilities or visual impairment.

Special education classrooms were also opened in public schools to educate students with visual impairment, blindness, hearing impairment, deafness, intellectual disabilities and autism. In addition, the Saudi Arabian government has enacted various special education and disability laws to ensure that students with disabilities receive 
free and appropriate education. For example, RRSEP, established by the Saudi Arabian Ministry of Education, manages and provides special education services for students whether in public schools or in special education schools. Disability law is another regulation recognized by the Saudi Arabian government to ensure that each individual with a disability can access appropriate and free rehabilitation, educational and mental health services offered via public organizations.

A number of recommendations, as presented in this paper, can be derived as critical pointers to areas and paths that need to be pursued in Saudi Arabian special education, based on the analysis made here on the issue of promoting inclusion of students with disabilities. The first thing to consider when it comes to inclusive education is the need to improve special education, according to the unique needs of the students. This observation finds support in the developments in special education which denotes the press for inclusion without the establishment of necessary supportive infrastructure for that inclusion.

Students with disabilities should be educated in least restrictive environments according to their needs and should be considered when making individual educational plans for the students. Therefore, laws for improvement in providing special education services in the Saudi Arabian nation need to be adopted. These laws will ensure that the following services are provided to the society: early identification, early intervention, and free and appropriate public education. These laws also include requirements of parent involvement, use of assistive technology and providing of transition services along with special education services.

Furthermore, in Saudi Arabia, there is a need to establish professional development programs to prepare teachers and other school staff for inclusive classrooms before rolling out the real process of inclusive learning for students with disabilities. In most cases, using different kinds of professional development methods such as the professional learning community will effectively improve the skills of teachers in their schools. Inclusive education is difficult to achieve when teachers are not adequately prepared for inclusion. Consequently, the teacher preparation programs in Saudi Arabian universities should develop programs that provide knowledge and skills for teaching students with disabilities in inclusive classrooms. To finish, study research should be conducted on the special education field in Saudi Arabia in order to measure how the special education services are provided, their effectiveness, and the advantages or disadvantages of inclusion.

\section{References}

Afeafe, M. (2000). Special Education in Saudi Arabia. http://www.khayma.com/education-technology/PrvEducation3.htm

Al-Ajmi, N. (2006). The Kingdom of Saudi Arabia: Administrators' and Special Education Teachers' Perceptions regarding the Use of Functional Behavior Assessments for Students with Intellectual Disabilities. Unpublished Doctoral Dissertation, Madison: University of Wisconsin-Madison.

Al-Kheraigi, F. S. (1989). Special Education Development in the Kingdom of Saudi Arabia from 1958 to 1987. Unpublished Doctoral Dissertation, Syracuse: Syracuse University.

Al-Mousa, N. (1999). Development Process of Special Education in Saudi Arabia. Riyadh: Directorate General of Special Education in Saudi Arabia.

Al-Mousa, N. (2010). The Experience of the Kingdom of Saudi Arabia in Mainstreaming Students with Special Educational Needs in Public Schools. Riyadh: The Arab Bureau of Education for the Gulf States.

http://unesdoc.unesco.org/images/0019/001916/191663e.pdf

Al-Otaibi, B., \& Al-Sartawi, Z. A. (2009). Related Services That Are Needed for the Students with Multiple Disabilities and Their Families in Saudi Arabia. http://www.dr-banderalotaibi.com/new/1.pdf

Alquraini, T. (2010). Special Education in Saudi Arabia: Challenges, Perspectives, Future Possibilities. International Journal of Special Education, 25, 139-147.

Alquraini, T. A. (2011). Teachers' Perspectives of Inclusion of the Students with Severe Disabilities in Elementary Schools in Saudi Arabia. Unpublished Doctoral Dissertation, Athens: Ohio University.

Alquraini, T., \& Dianne Gut, D. (2012). Critical Components of Successful Inclusion of Students with Severe Disabilities: Literature Review. International Journal of Special Education, 27, 42-59.

Al-Wabli, A. (1996). Related Services That Are Provided for Students with Intellectual Disabilities in Special Education Institutes in Saudi Arabia. Journal of Education, 20, 191-123.

Burnette, B. (2002). How We Formed Our Community. National Staff Development Council, 23, 51-54.

Cushing, L. S., Clark, N. M., Carter, E. W., \& Kennedy, C. H. (2005). Access to the General Education Curriculum for Students with Significant Cognitive Disabilities. Teaching Exceptional Children, 38, 6-13. 
Forlina, C., \& Chambers, D. (2011). Teacher Preparation for Inclusive Education: Increasing Knowledge but Raising Concerns. Asia-Pacific Journal of Teacher Education, 39, 17-32. http://dx.doi.org/10.1080/1359866X.2010.540850

IDEA Partnership (2007). Response to Intervention: Policy Considerations and Implementation. www.ideapartnership.org/documents/RTI-intermediate-ppt-7-30-07.ppt

Johnson, D. R., \& Merrill, P. (2000). Issues Influencing the Future of Transition Programs and Services in the United States: A Collection of Articles by Leading Researchers in Secondary Special Education and Transition Services for Students with Disabilities. http://www.ncset.org/publications/related/NTN_Transition_Issues.pdf

Loiacono, V., \&Valenti, V. (2010). General Education Teachers Need to be Prepared to Co-Teach the Increasing Number of Children with Autism in Inclusive Settings. International Journal of Special Education, 25, 24-32.

Ministry of Education of Saudi Arabia (2002). Rules and Regulations of Special Education. https://www.moe.gov.sa/Arabic/PublicAgenciesAndDepartments/BoysEducationAgency/SpecialEducation/DocumentsLib raries/RulesAndRegulations/se rules.zip

Ministry of Education of Saudi Arabia (2012). Statistical Manual of Institutes and Special Education Programs for the Academic Year 2012/2013.

Proctor, R., \& Niemeyer, J. A. (2001). Preservice Teacher Beliefs about Inclusion: Implications for Early Intervention Educators. Journal of Early Intervention, 24, 55-66. http://dx.doi.org/10.1177/105381510102400108

Resch, J. A., Mireles, G., Benz, M. R., Grenwelge, C., Peterson, R., \& Zhang, D. (2010). Giving Parents a Voice: A Qualitative Study of the Challenges Experienced by Parents of Children with Disabilities. Rehabilitation Psychology, 5, $139-150$. http://dx.doi.org/10.1037/a0019473

Russell, M., Bebell, D., O'Dwyer, L., \& O’Connor, K. (2003). Examining Teacher Technology Use: Implications for PreService and In-Service Teacher Preparation. Journal of Teacher Education, 54, 297-310. http://dx.doi.org/10.1177/0022487103255985

Smith, A. (2006). Access, Participation, and Progress in the General Education Curriculum in the Least Restrictive Environment for Students with Significant Cognitive Disabilities. Research \& Practice for Persons with Severe Disabilities, 31 , 331-337.

Will, M. C. (1986). Educating Children with Learning Problems: A Shared Responsibility. Exceptional Children, 52, 411415.

Wong, E. M. L., Li, S. S. C., Choi, T. H., \& Lee, T. N. (2008). Insights into Innovative Classroom Practices with ICT: Identifying the Impetus for Change. Educational Technology \& Society, 11, 248-265.

Worcester, J. A., Nesman, T. M., Raffaele Mendez, L., M., \& Keller, H. R. (2008). Giving Voice to Parents of Young Children with Challenging Behavior. Exceptional Children, 74, 509-525. 